\title{
Монашество как форма трансляции религии в эпоху гонений на Церковь в 1960-1970-х гг. (по материалам Центральной России)
}

\author{
прот. Дмитрий Сазонов \\ Общецерковная аспирантура им. св. Кирилла и Мефодия, \\ Россия, \\ ORCID: 0000-0001-9292-6473 \\ sazonow63.12@gmail.com
}

rev. D. Sazonov, Monasticism as a form of religion translation in the era of persecution of the Church in the 1960s and 1970s (based on materials from Central Russia), Elpis, 22 2020: 55-59.

ks. D. Sazonov, Monastycyzm jako forma przekazu religii w dobie prześladowań Kościoła w latach $1960-1970$ (na podstawie dokumentów z centralnej Rosji), Elpis, 22 2020: 55-59.

\begin{abstract}
The article, based on the mentioned sources, discusses the role of monastics who were forced to switch to the parish ministry in the conditions of persecution. Despite the absence of legal monasteries, many churches and Bishop's houses formed monastic communities. The monks became guides of faith and performed the functions that they previously performed in monasteries. In the case of these communities having a legal status was not required. Many of them, despite their illegal status, were centers of faith, catechism, and charity. The study found that thanks to monastic communities and their illegal status, it was possible to transmit the foundations of the faith and intact Church tradition until the 1990s.

Streszczenie: Artykuł na podstawie źródeł ujawnia rolę mnichów, którzy w warunkach prześladowań musieli przejść do posługi parafialnej. Pomimo braku legalnych klasztorów, przy wielu świątyniach i domach biskupich powstawały wspólnoty monastyczne. Mnisi stali się przewodnikami wiary i wypełniali funkcje wcześniej realizowane w monasterach. Regulacja statusu prawnego takich społeczności nie był potrzebny. Wiele z nich, mimo swojego nielegalnego statusu, tworzyło centra wiary, katechizacji i miłości. W trakcie badań okazało się, że dzięki wspólnotom monastycznym i ich nielegalnemu statusowi udało się przekazać podstawy wiary i nienaruszoną tradycję kościelną aż do 1990 roku.

Аннотация: В статье на основании источников раскрывается роль монашествующих, которые в условиях гонений вынуждены были перейти к приходскому служению. Несмотря на отсутствие легальных монастырей, при многих храмах и архиерейский домах образовывались монашеские общины. Они стали проводниками веры и выполняли функции, которые выполняли монашествующие в монастырях. Легальный статус таким общинам был не нужен. Многие из них при своем нелегальном статусе были очагами веры, катехизации и благотворительности. В ходе исследования удалось выяснить, что благодаря монашеским общинам и их нелегальному статусу удалось передать основы веры и неповрежденную церковную традицию вплоть до 1990-е годов.
\end{abstract}

Keywords: nun, monastery, persecution, monk in the world

Słowa kluczowe: inokini, monaster, prześladowania, mnich w świecie

Ключевые слова: инокини, монастырь, обитель, гонения, монах в миру

В книге воспоминаний об архимандрите Павле (Груздеве) «Последний из Мологи» говорится об атмосфере 1960-х годов, когда после заявлений руководства страны о «последнем попе», закрытии храмов и монастырей, слово «последний» все чаще звучало в церковной среде - «последний наместник», «последняя игумения», «последний монах». Себя архимандрит Павел чувствовал последним монахом из Мологи, из намоленного града Китежа, ушедшего под воду. В книге воспоминаний об о. Павле приводится случай, произошедший с ним при посещении им Троице-Сергиевой Лавры. Приехав после лагерного срока в обитель преподобного Сергия и увидев там служащего монаха, он не поверил, что еще в России есть «живые монахи» (Černyh, 2013, с. 301-302). На основании многих доку- ментов местных и епархиальных архивов, можно сделать вывод, что «последние» монахи и монахини стали теми семенами, которые дали великий плод - возрастили будущую генерацию Церкви.

Отметим, что в связи с антирелигиозной обстановкой в стране, партийные лидеры которой провозгласили построение коммунизма в ближайшие 20 лет, наряду с тайными священническими хиротониями (немногочисленными), в 1960-1980-е гг. имели место тайные монашеские постриги, которые практиковались во всех епархиях Русской Православной Церкви. Совершались они ввиду ограниченного количества монастырей, ограниченного количества прописываемых в них насельников, а также, желания совмещать светскую работу и монашеское делание. 
К 1962 году в Русской Православной Церкви из действующих в послевоенное время 63 монастырей осталось 16 (Škarovskij, 2005, с. 391). В числе первых подвергались закрытию монастыри действовавшие на бывших оккупированных территориях, включенных после войны в состав советских республик: Западной Украины, Западной Белоруссии, Прибалтики, Молдавии, юга Одесской области. Монашествующие и трудники из обителей переводились в другие монастыри, либо разгонялись, либо переезжали в Центральную Россию, где нашли себе применение - мужчины-монахи на приходском служении в качестве настоятелей, монахини - в качестве псаломщиц, просфорниц, алтарниц, сторожей. В 1960-1970-е гг. значительным явлением было женское служение при храме. По воспоминаниям монахини Никодимы (Волубаевой), она переехала после закрытия монастыря в Украине вместе с монахиней Серафимой (Мигуновой) в Кострому, где архиепископ Кассиан (Ярославский) предложил им потрудиться при Введенском храме города Галича, где они и остались (Starec-arhipastyr'. Arhiepiskop Kassian (Âroslavskij), 2019, с. 39).

Помимо открытой ликвидации монастырей власти предпринимали меры, приводившие к сокращению количества монашествующих в монастырях: отказ в прописке, непомерные налоги, оплата займов. Женщины, за неимением церковников-мужчин во всякой храмовой работе помогали священникам - настоятелям. Даже после закрытия храма они оставались на «посту» - берегли храм и утварь от разграбления, приходили и молились в закрытых храмах в дни церковных праздников, украшали и убирали их, наводили порядок. Примером такого служения является жизнь преподобной Анемаисы (Смертиной) Острецовской исповедницы (+1963) которая «в нужде, в труде, в молитве» почти круглосуточно находилась в острецовском храме и сохранила его во время гонений, вплоть до своей смерти в 1964 году (Sazonov, 2016, с. 118-121). Угличская исповедница Ираида Котова, после возвращения из ссылки в 1955 году в родную деревню делала все от нее возможное, чтобы воспрепятствовать разорению закрытого властями Успенского храма: она прогоняла назойливых туристов, заменяла сломанные замки новыми. Учила деревенских детей молитвам, рассказывала о праздниках, «совершала богослужения» в родительском доме. В бане, где она жила, в 1962 году была окрещена ее внучка, изредка приезжие священники совершали Литургию (Men'kova, 2017, с. 75-76).

При кафедральных соборах и архиерейских домах собирались насельницы, которые создавали небольшие женские монашеские общины. К ним, со временем, присоединялись желающие иноческой жизни другие женщины. Например, при Воскресенском кафедральном соборе г. Костромы находилась такая община: монахиня Феофания (Иванова), монахиня Варсонофия (Голубева), инокиня Тавифа (Веселова). Они все были псаломщицами, пекли просфоры, следили за ризницей, убирали храм, следили за порядком в храме. Нахо- дились в церкви почти круглосуточно. Жили в храмовой сторожке. Таковой была община вернувшихся из заключения сестер Феоктисты, Палладии, Анастасии (Кулаковых) в 1950-е годы при Христорождественском храме в с. Княжево Красносельского р-на Костромской области (Gosudarstvennyj arhiv Âroslavskoj oblasti, 1963, с. 39). При архиерейском доме, в котором жил костромской архиепископ Кассиан (в нем также располагалось епархиальное управление) состояли и келейник владыки иеродиакон Паисий (Козлов) и монахиня Серафима (Разгуляева) (Starec-arhipastyr'. Arhiepiskop Kassian (Âroslavskij), 2019, с. 21). В бытность служения будущего архиепископа Амвросия (Щурова) в с. Толпыгино Ивановской области его келейницей была монахиня Нина, которая вела все хозяйство молодого иеромонаха. Затем к ней присоединились еще несколько монахинь, собралась целая монашеская община (Fedotov, 2017, c. 42)

Некоторая часть насельников монастырей уходила на приходское служение от суеты «новой жизни». Там, вдали от «мира», образовывались из духовных чад старцев малые общины монашествующих, в основном, женщин. Свой уход на приходское служение они мотивировали распространенным в то время мнением, что современные монахи были «не те, что раньше» - не соблюдали устав обители, вносили непозволительную для иноческой жизни суету, обрастали имениями. Архимандрит Таврион (Ботозский) покинул Глинскую пустынь, затем последовали Почаев, Уфа, сельские приходы Ярославской области. Везде он создавал братские общины из желавших монашеской жизни женщин. Конечной обителью его жизни стала Преображенская пустынька под Ригой. Он считал, что монахи должны служить людям, а братия покинутой им Гефсиманской обители считала, что миряне должны служить монахам, а монахи лишь молиться за них. Он видел причину обмирщения монашества в том, что за время «сидения» в лагерях монахов воспитанных в традициях дореволюционного строя обителей, выросли новые поколения, многие из которых только открывали для себя Евангелие, воцерковлялись. Неофиты, принявшие монашество в 1960-х годах не имели преемственного опыта жизни в обители. Характеризуя личность архим. Тавриона историк С. Бычков пишет о «бодрствующей совести» этого монаха, которая давала ему силы и способности сопротивляться конформизму и не склоняться перед тоталитаризмом» (Byčkov, 2007, c. 238). Он пишет, что не найдя идеала монашества в современных монастырях архим. Таврион свое видение миссионерского служения монаха сформировал в приходских условиях. Современный монах, по его мнению, - это культурный, начитанный, человек, сведущий в Священном Писании и святоотеческом опыте, проповедующий евангельские истины не только словами, но прежде всего - образом жизни (Byčkov, 2007, с. 246). В 1960-1970-е годы монахини из закрытых монастырей, и те, кто не нашел свое место в действующих монастырях собирались обычно у духовных старцев 
на приходах, где образовывали приходские монастыри. Например, лаврский архимандрит Алексий (Казаков) перебрался под Куйбышев (Самару), где стал приходским священником. В свое письме архим. Павлу (Груздеву) он писал: «В Лавре (Троице-Сергиева Лавра) я был давно. И прямо скажу: охоты нет. Все новые люди и порядки. Все натянуто, надуто, чопорно. Так потихоньку служу» (Černyh, 2013, с. 302-303). Многие монахи сознательно уходили на захудалые вдали от городов приходы, чтобы в глуши созидать «внутреннего человека», идеал они видели в уходивших в пустыню Северной Фиваиды монастырских насельниках XIV$\mathrm{XV}$ веков. На карагандинском приходе архимандрита Севастиана (Фомина) основу общины составили «родные по духу» сестры, которые искали духовного руководства после закрытия Оптиной пустыни. Первой приехала инокиня Шамординского монастыря Агриппина, которую батюшка определил петь на клиросе. Затем приехала инокиня того же монастыря Феврония, ей было дано задание вести домашнее хозяйство. Вскоре приехали две девушки из купеческой семьи. Одна из них, инокиня Варвара, обладавшая хорошим голосом и прекрасной памятью стала уставщицей в храме, и получила наименование «миротворица» за то, что всегда старалась мирить ссорящихся. Монахиня Агния, бывшая духовная дочь Оптинского старца Варсонофия написала храмовые иконы. Они же, сестры монахини составили двадцатку, которая ходатайствовала об открытии общины в Караганде (Aleksandr, mitr., 2017, c. 417).

Служение странноприимничества и помощи ближним отличало жизнь сестер Анисии, Матроны и Агафии, подвизавшихся в селе Ялтуново Шацкого района Рязанской епархии, которые духовно окормлялись на приходе, помогали репрессированным священнослужителям, возвращавшимся в родные места после отбывания лагерных сроков. Своим служением Богу они не только сохранили веру в себе, но многих привлекли к Церкви. Даже своим наличием, своим присутствием, они укрепили веру многих. При Успенском приходе с. Тетеринское Нерехтского р-на Костромской области бывшим насельника Киево-Печерской Лавры архим. Поликарпом (Будаква), назначенном туда в октябре 1963 года, была устроена небольшая монашеская община. Впоследствии году она послужила основанием для открытия в 1993 году Успенского женского Тетеринского монастыря (Monastyri Kostromskoj eparhii, 2009 , с. 45). При московском храме Ильи Обыденного трудились просфорницами монахини бывшего Зачатьевского монастыря Антонина (Яковлева) и Нина (Корнева). Жили они скудно, все заработанные деньги отдавали нуждающимся, были строгими постниками. «Высокий образ духовной жизни приводил к монахиням очень разных людей - свидетельствовала ставшая ее духовной дочерью Т. Г. Маклакова, - от нищенки у храма Ильи Обыденного до рафинированных интеллигентов, для которых монахиня Антонина была духовной матерью. Некоторые из посетителей матушки при- няли тайный постриг. Всем она помогала преодолевать трудности и соблазны в духовной и мирской жизни» (Monastyrskie staricy, 2015, с. 98).

В 1928 году в подмосковном поселке Барвиха после закрытия Зачатьевской обители проживало 14 сестер, которые создали пошивочную артель. В 1932 году монастырское подворье уничтожили, монахинь арестовали и вывезли из монастыря. Некоторым из них удалось бежать. Сначала они укрывались в землянках, затем жили на квартирах у верующих крестьян. Так в пос. Жуковка оказалась монахиня Филарета (Евгения Ивановна Дегтярева) - «тетя Евгеша», так ее звали местные жители. Она учила детей местных жителей Закону Божиему, молитвам, читала им Евангелие и Псалтырь. Фактически она передавала веру, была катехизатором подрастающего поколения. «Она жила в маленькой комнатке, - вспоминает жительница Барвихи Анна, там стояла кровать, стол, стул, и вся она была в иконах, и лампады висели < . .> Когда мы оттуда шли, а расстояние около двух километров, то не шли, а как будто на крыльях летели - такое состояние было возвышенное. Я всегда с нетерпением ждала, когда мы с мамой еще туда пойдем» (Monastyrskie staricy, 2015, с.100-101). Монахини составляли ядро верующих на приходе - не только выполняли обязанности по храму, но и были «народными катехизаторами». Конечно, таковыми их можно именовать условно, однако, в меру той окружающей их обстановки, они являли образ непокоренной Церкви. В местностях, где не было храма, а таковых, например, в Центральной России, Казахстане, Сибири и на Дальнем Востоке страны было много, монахини «крестили» детей, читали по покойнику и отпевали, в храмах, где уже не было священника собирались и проводили богослужения.

Монашеские общины «в миру», состоящие из насельниц закрытых монастырей становились духовными центрами, средоточием духовной жизни, где люди духовного склада находили приют, заботу и единомышленников, а миряне воцерковлялись. Работали они на светских службе, а жизнь вели монашескую. Многие пациенты и окружающие люди не могли догадаться, что врач-клинист В. И. Жмурова долгие годы лечившая митрополита Николая (Ярушевича) была монахиней, а затем схимницей Вероникой (Svencickij, 2009 , с. 159). Многие из зачатьевских монахинь после закрытия монастыря проживали в Александрове, носили светскую одежду. «Посещавшие Москву сестры всегда находили приют и ночлег в доме по 3-му Зачатьевскому и неизменную заботу монахини Антонины и ее келейницы Настеньки (будущей схимонахини Нины)» - свидетельствовали очевидцы, - Их квартира в доме №14 в 3-м Зачатьевском переулке стала прибежищем для страждущих и очагом духовной жизни. Их труды, помощь ближним и самоотверженная жизнь лучше всяких слов (иногда даже проповеди), способствовали открытию в людях потребности веры и воцерковляли многолетних атеистов» (Monastyrskie staricy, 2015, c. 97). 
Не подлежит сомнению, что большинство священнослужителей и ушедших в катакомбы были монашествующими. Мнение прот. Константинова, как и мнение А. Беглова, подтверждают данные статистики - даже к середине 1960-х годов определенное количество православных приходов в СССР находилось на нелегальном положении и не было зарегистрировано. По данным Совета по делам Русской Православной Церкви на 1 января 1962 года в стране действовало 783 нелегальные общины. Официально зарегистрированных приходов РПЦ было 10221, а 783 были не зарегистрированы, т.е., 6,5\% общин, применительно к количеству зарегистрированных, было вне правового поля, вне контроля уполномоченных и советских органов (Gordun, 1992, с. 20). Незарегистрированные общины были реальностью церковной жизни вплоть до 1990-х гг. XX века. Существование этих нелегальных общин свидетельствовало о высокой религиозности населения, которое желало жить согласно своим религиозным принципам представлениям, а также, активной богослужебной жизнью. Для многих епископ Афанасий (Сахаров) был духовным наставником, вокруг которого объединялись ищущие духовной жизни люди, многие их которых принимали затем монашеский постриг. К архим. Тавриону (Ботозскому), архим. Павлу (Груздеву), архим. Борису (Холчеву) и Михею (Хархарову) ездили верующие люди со всех концов страны. Они образовывали общины, которые под мудрым руководством наставников не только сохраняли традиции обряда и веры, но сами затем становились воцерковителями новых поколений православных христиан.
Отметим, что в 1962-1964 гг. к различным наказаниям по пунктам 227 статьи было приговорено более 200 человек, среди которых были представители «православного подполья», а также, сектанты. Уместно будет сказать, что количество незарегистрированных общин в начале 1960-х годов в Поволжье превышало количество легальных приходов, что подтверждает активный характер общинной жизни.

В секретной записке председателя СДР К. М. Харчева говорилось о деятельности нелегальных общин проводящих богослужения на открытом воздухе, или в неприспособленных для такого рода мероприятий помещениях. Такое состояние нахождения религиозных общин объяснялось тем, что несмотря на ходатайства верующих, их ходатайства об открытии храмов игнорировались Советом по делам религий, а общины не регистрировались. Он говорил о тысячах населенных пунктов, где присутствовали нелегальные общины. «В тысячах населенных пунктах, где группы верующих различных конфессий проводят богослужения нелегально, в связи с тем, что их ходатайства об открытии приходов необоснованно отклоняются» - говорил К. Харчев (Filippov, 2009, с. 489). Почти в каждой из этих нелегальных общин присутствовали монашествующие.

Исходя из приведенных источников, следует признать, что монашество во время т.н. «хрущевских гонений» сыграло огромную роль в качестве транслятора веры и передало ее учение и традиции в неповрежденном виде, способствуя во время прекращения гонений возрождению Русской Церкви.

\section{Bibliografia}

Aleksandr (Mogilev), mitr. (2017). Bol'še vsego nasvete lûbi Cerkov' Božiû. Astana. [Александр (Могилев), митр. (2017). Больше всего на свете люби Церковь Божию. Астана].

Byčkov, S. (2007). Stradnyj put' arhimandrita Tavriona. M.:Izdatel'stvo «Tètis Pablišn». [Бычков, C. (2007). Страдный путь архимандрита Тавриона. М.: Издательство «Тэтис Паблишн»].

Černyh, N. (2013). Poslednij iz Mologi. Izdatel'stvo: Kitezh. [Черных, Н. (2013). Последний из Мологи. Издательство: Китеж].

Fedotov, A. A. (2017). «ÂA vozželal Zapovedejtvoih». Pamâti arhiepiskopa Amvrosiâ (Ŝrova). Ivanovo. [Федотов, А. А. (2017). «Я возжелал заповедей Твоих». Памяти архиепископа Амвросия (Щурова). Иваново].

Filippov, B. A. (2009). Očerki po istorii Rossii HH vek: Učeb. Posobie. M.: Izd-vo PSTGU [Филиппов, Б. А. (2009). Очерки по истории России $X X$ век: Учеб. Пособие. М.: Изд-во ПСТГУ].

Gordun, S., prot. (1992). Russkaâ Pravoslavnaâ Cerkov'v period s 1943 po 1970 god. (Kratkijistoričeskij očerk). Žurnal Moskovskoj Patriarhii, №1. [Гордун, С., прот.(1992). Русская Православная Церковь в период с 1943 по 1970 год. (Краткий исторический очерк). Журнал Московской Патриархии, №1].

Gosudarstvennyj arhiv Âroslavskoj oblasti (GAYAO). (1963) F. r-3698. Op.2. D. s-11244. [Государственный архив Ярославской области (ГАЯО). (1963) Ф. р-3698. Оп.2. Д. c-11244].

Men'kova, I. G. (red). (2017). Drugoj žizni neželaû. Ispovednica Ugličskaâ Iraidatihova, podvig dlinoû v žizn'. Rybinsk. [Менькова, И. Г. (ред). (2017). Другой жизни не желаю. Исповеднииа Угличская Ираида Тихова, подвиг длиною в жизнь. Рыбинск].

Monastyri Kostromskoj eparhii. (2009). Kostromskie Eparhial'nye Vedomosti. №6. Iûn'. Kostroma. [Монастыри Костромской епархии. (2009). Костромские Епархиальные Ведомости. №6. Июнь. Кострома].

Monastyrskie staricy. (2015). Monastyrskij vestnik. №11(23) noâbr'. Moskva [Монастырские старииьы. (2015). Монастырский вестник. №11(23) ноябрь. Москва].

Sazonov, D. prot. (red.).(2016). Kostromskâ̂ Golgofa. Kostroma. [Сазонов, Д. прот. (ред.).(2016). Костромская Голгофа. Кострома].

Škarovskij, M. V. (2005). Russkaâ Pravoslavnaâ Cerkov' pri Staline i Hruŝeve (gosudarstvenno-cerkovnye otnošeniâ 
v SSSR v 1939-1964 godah). Moskva. [Шкаровский, М. В. (2005). Русская Православная Церковь при Сталине и Хрущеве (государственно-иерковные отношения в СССР в 1939-1964 годах). Москва].

Starec-arhipastyr'. Arhiepiskop Kassian (Âroslavskij). K 120-letîu so dnâ roždeniâ. 1899-2019. Kostroma. [Семенова, А.В. (ред.). (2019). Старец-архипастьрь. Архиепископ
Кассиан (Ярославский). К 120-летию со дня рождения. 1899-2019. Кострома].

Svencickij, A. B. (2009). Nevidimye niti. Cerkov', sobytiâ, lûdi. M.: Izdatel'stvo Moskovskoj Patriarhii [Свенцицкий, А. Б. (2009). Невидимые нити. Церковь, события, люди. М.: Издательство Московской Патриархии].

Rozmiar artykułu: 0,6 arkusza wydawniczego 